\title{
POST OPERATIVE NAUSEA AND VOMITING, ITS CAUSES, AND THE WAY OF ITS PREVENTION AND TREATMENT
}

\author{
Surendra Maharjan ${ }^{1 *}$, Zhang Bing ${ }^{2}$
}

\begin{abstract}
Affiliation
1. Consultant, Department of Anesthesia and ICU, National Trauma Centre (National Academy of Medical Seciences), Nepal.

2. Professor, Department of Anesthesia Harbin Medical University), China.
\end{abstract}

\section{ARTICLE INFO}

Received : 07 July, 2020

Accepted : 21 January, 2021

Published : 15 June, 2021

(C) Authors retain copyright and grant the journal right of first publication with the work simultaneously licensed under Creative Commons Attribution License CC - BY 4.0 that allows others to share the work with an acknowledgment of the work's authorship and initial publication in this journal.

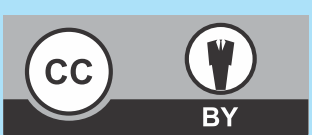

RA 2

DOI: https://doi.org/10.3126/bjhs.v6i1.37647

* Corresponding Author

Dr. Surendra Maharjan Consultant

Department of Anesthesia and ICU National Trauma Centre National Academy of Medical Sciences, Nepal Email ID: surendra4357@gmail.com ORCID ID: https://orcid.org/0000-0002-1982-7783

\section{Citation}

Surendra Maharjan, Zhang Bing. Post Operative Nausea and Vomiting, its Causes, and the Way of its Prevention and Treatment. BJHS 2021;6(1)14. 1405-1415.

\section{ABSTRACT}

Postoperative nausea and vomiting is still occurring in one third of the patient undergoing surgery under general anaesthesia even after following the guidelines and using multi modal approach for its prevention. Lots of studies have been done for its prevention but very few studies are done for its treatment in Post anaesthetic care unit after the failure of prophylaxis. The purpose of this article is to know about the risk factor, incidence of nausea and vomiting after surgery, its mechanism, available medication (pharmacological and nonpharmacological), reducing risk factor, and mainly to know about the method of using the antiemetic medication in PACU after the failure of the prophylactic medication.

\section{KEYWORDS}

nausea, prophylaxis failure, rescue drugs, vomiting 


\section{Introduction}

Postoperative nausea and vomiting is one of the most commonly experienced side effects of the general anaesthesia which can increase duration of the post anaesthetic care unit stay and leads to increase in duration of hospital stay and increase in financial expence. ${ }^{1-4} \mathrm{PONV}$ is about $20 \%$ to $30 \%$ on the patient under general anaesthesia and is almost about 70-80\% inthe high-riskpatient. ${ }^{2,3}$ Female gender, history of motion sickness or PONV, postoperative opioid use and non-smoking status are regarded as a major risk factor for PONV². Multiple guidelines are available to achieve the target of prevention of PONV.-5 In ambulatory surgery, $0.1 \%$ to $0.2 \%$ patient get admitted due to PONV. ${ }^{5-7}$ PONV refers to the sensation of nausea and vomiting or retching for up to 24 hours post operation. Researchers had shown that patients are willing to pay more to get rid of PONV. ${ }^{8}$ Though multi modal treatment strategies with multiple antiemetic and nonpharmacologicalmethods arebeing used to prevent PONVwe still have an occurrence of PONV in PACU.Enhanced recovery after surgery (ERAS) is all about reduction of morbidity, decrease the hospital stay and recover fast. Thus prevention and treatment of PONV is also one of the many goals of the ERAS. ${ }^{9}$

The main objective of this review is to gain knowledge about the cause of the nausea and vomiting that occurs in the patient who undergoes surgery under general anaesthesia and the ways of its reduction and prevention and what can be done in case of occurrence of Post-operative nausea vomiting. This article also enlightens us about the beneficial effect of the prevention of PONV on patient recovery and early discharge from hospital after undergoing surgery under general anaesthesia.

This review article included altogether 113 literatures .We searched online pubmed and medline for articles published till 2019 using keywords - post operative nausea and vomiting PONV prophylaxis, and rescue.

\section{Pathophysiology of nausea and vomiting}

Vomiting is triggered in the vomiting centre which comprises of thelateral reticular formation and nucleus tractussolatirius of medulla which is inside the bloodbrainbarrier. The most important trigger zone for vomiting is CTZ (chemical trigger zone) which lies in the area postrema on the wall of the fourth ventricle andis outside the bloodbrainbarrier. Opioids and volatile anaesthetic agents act on CTZ to trigger nausea and vomiting. Vestibular and gastrointestinal vagal afferent send emetogenic stimuli to the vomiting centre and stimulate for nausea and vomiting. Input form higher cortical centres, the cerebellum, glossopharyngeal nerve stimulation and vagal stimulation can also induce the vomiting centre and cause nausea and vomiting. Vestibular system also contributes in the generation of nausea and vomiting via motion and vertigo. Figure 1.

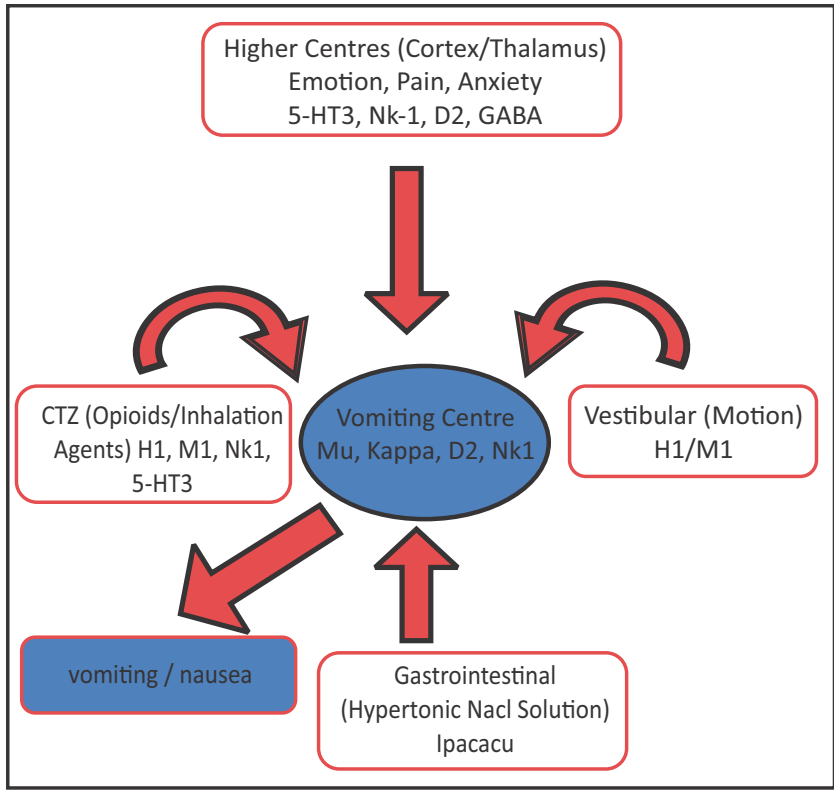

Figure-1: Pathophysiology of nausea and vomiting

CTZ:chemical trigger zone; $\mathrm{H} 1$ :Histamine 1 receptor; NK1:neurokinin 1 receptor; M1:Mu 1opoid receptor; 5HT3:Serotonin receptor; D2:Dopamine 2 receptor; GABA: Gammaammuno-butyric acid receptor; Nacl:sodium chloride.

\section{Risk factor for PONV}

There are several risk assessment methods for predicting the risk of PONV. In 1999 Apfelproposed simplified risk score with gender, non-smoker, history of PONV or motion sickness and postoperative opioid use as risk factor as shown in table 1 which is the most common risk score used to assess the risk of PONV. ${ }^{2}$ However before Apfel, Palazzo in 1993 had also studied risk factor for PONV in orthopaedic patient with gender, history of previous postoperative sickness, postoperative opioids and interaction between gender and previous history of sickness being a significant independent risk factor for PONV; history of motion sickness being weakly linked. ${ }^{10}$ Koivuranta in 1997 also had given five strong predictors of PONV i.e. female gender, previous postoperative nausea and vomiting, duration of operation over 60 mins, history of motion sickness and non-smoking. ${ }^{11}$ Sinclair included duration and type of anaesthesia and type of surgery along with age, sex, smoking status, history of previous PONV in a risk factor of PONV.

\section{Table 1: Risk factors of PONV in adult}

\begin{tabular}{|l|c|c|c|}
\hline Risk factor & Points & Score & $\begin{array}{c}\text { PONV } \\
\text { risk \% }\end{array}$ \\
\hline None & 0 & 0 & 10 \\
\hline Female gender & 1 & 1 & 20 \\
\hline Non smoker & 1 & 2 & 40 \\
\hline $\begin{array}{l}\text { History of PONV /motion } \\
\text { sickness }\end{array}$ & 1 & 3 & 60 \\
\hline Postoperative opioids & 1 & 4 & 80 \\
\hline Total & $\mathbf{0 - 4}$ & & $\mathbf{1 0 - 8 0}$ \\
\hline
\end{tabular}

Simplified risk score in adults (Based on Apfel's simplified risk score $)^{2}$ 
The risk factor of PONV can be either patient related, anaesthesia related or surgery related.

\section{Patient related \\ Gender}

Female gender suffers three times more PONV than the male. ${ }^{13-15}$ The high prevalence of PONV in female gender isbelieved to be caused by thefluctuation of female hormone during menstruation cycle. ${ }^{16,17}$ This relationship is limited to the adults only as there is no difference in PONV in children before puberty and elderly above eighty years. ${ }^{18,19}$ However many studies have failed to show the differences in PONV in different stages of the menstruation cycle. ${ }^{17}$ Some authors have shown that this gender difference in PONV is also seen in old age when hormones levels (gonadotropins) are same in both male and female. ${ }^{20}$

\section{Smoking status}

Non-smokers have twice more incidence of PONV than the smokers. ${ }^{15}$ The exact mechanism of this not understood completely. However Apfel and colleagues have proposed that smoking cigarettes might have an effect in dopamine receptor but there isn't any extra pyramidal side effects seen in smokers to rely on their suggestion. ${ }^{21}$ Studies have shown that polycyclic aromatic hydrocarbons in the cigarette induces the cytochrome p450 enzymes which increases or fasten the metabolism of the emetogenic volatile anaesthetics and drugs which helps in reduction of PONV. ${ }^{22,23}$

\section{Previous history of PONV and motion sickness}

Previous history of motion sickness or PONV increases the occurrence of PONV., ${ }^{2,15}$ There is three times more chance of occurring nausea and vomitingin general anesthesia in these patient. ${ }^{14}$

\section{Age}

In younger children less than 3 years, the incidence of PONV is relatively low. ${ }^{24}$ In adult PONV decreases as the age increases. ${ }^{13}$ Paediatric patients have a more chances of having POV(postoperative vomiting) than adults with school children having incidence of about $34-45 \%{ }^{24}$ Infants have lowest incidence with about $5 \%$ of occurrence and preschool children have an incidence of about $20 \% .^{24}$ Adults younger than 50 years of age have more prone to PONV than those who are older than 50 years of age. ${ }^{25}$ The likelihood of PONV decreases by $13 \%$ for addition of each 10 -yrs in age. ${ }^{12}$

\section{Obesity}

More obese patients are at increased risk of PONV. ${ }^{26}$ It may be due to the adipose tissue which obese patient have more in comparison to the non-obese patient which can store more volatile anaesthetics which in return can aggravate PONV. ${ }^{26}$ Also Obese patient are more prone to suffer from gastrointestinal disease, liver disease, have larger gastric volume, and have increased incidence of gastric oesophageal reflux disease, these all factor can increase incidence of
PONV. $^{26}$ In addition, obese patient are difficult to mask ventilate which also causes more gastric gas extension and can lead to PONV. ${ }^{26}$ However recent researches have shown that obesity don't have significant effect on PONV. ${ }^{27}$

\section{Preoperative Anxiety}

Preoperative anxiety can increase the incidence of PONV. ${ }^{13,26}$ Pre-operative anxiety increases the stress hormones which delays the gastric emptying and increase the gastric volume and increase the probability of nausea and vomiting. ${ }^{28}$ When these stress hormones (epinephrine and nor epinephrine) are injected to the ventricles of the cats they have induced vomiting in the cats. ${ }^{29}$

\section{Anaesthesia related Inhalational anaesthetics}

Volatile anaesthetics causes early post-operative period (first 2-6 hours) PONV and there is no difference in incidence of PONV with the use of halothane isoflurane, enflurane, and sevoflurane. ${ }^{30,31}$ The incidence of PONV with sevoflurane and desflurane is also same. ${ }^{32}$ The occurrence of PONV with volatile anaesthetics depends upon the concentration and duration of use of volatile anesthetics. ${ }^{30}$ Increase in the duration and concentration of volatile anaesthetics increases the incidence of PONV. ${ }^{30,32}$

\section{Nitrous oxide (N20)}

$\mathrm{N}_{2} \mathrm{O}$ can increase the incidence of PONV which has been shown by many studies in the past. ${ }^{33,35}$ Nitrous oxide stimulates nausea and vomiting mainly by following mechanisms-

1) Catecholamine release by stimulation of sympathetic nervous system. ${ }^{29}$

2) Stimulation of vestibular system by changing middle ear pressure. $^{36}$

3) Abdominal extension caused by the exchange of nitrous oxide and nitrogen with the inhalation gas in abdomen went during mask ventilation. ${ }^{37}$

4) Releasing endogenous opioid peptides and activating the area postrema of the brain. ${ }^{35}$

However some studies have failed to show the significant role of nitrous oxide in PONV. ${ }^{38,40}$

\section{Duration of anaesthesia}

Increase in the length of anaesthesia increases the occurrence of PONV. ${ }^{3-5}$ It has been shown that 30 minutes increase in time of surgery increases the risk of PONV by $59 \% .{ }^{12}$ It is because of use of more emetogenic drugs in long surgeries. ${ }^{12}$

\section{Post-operative opioid use}

Opioids induces nausea and vomiting by activating CTZ. Opioids use is one of the major risk factor of PONV. ${ }^{3,4}$ Gregory $W$. Roberts have shown that reduction of opioid dose to half reduces the incidence of PONV by the $6 \% .{ }^{41}$ The author also showed that there is a strong logarithmic dose -response relationship between postoperative opioid dose and POV as well as PON (post-operative nausea). ${ }^{41}$ Patient controlled analgesia and epidural opioids were a marker for large 
-dose opioid use and was associated with POV in the 24-h postoperative period of $41 \%$ and $31 \%$ respectively, compared with $11 \%$ for other patients not using both of them. ${ }^{41}$ A woodhouse showed that duration of dose delivery of opioids with PCA also effect the PONV. ${ }^{42}$ The author administered PCA morphine over 5 min which was associated with a more increase in the intensity of retching and vomiting compared with patients receiving PCA morphine over 40 seconds. ${ }^{42}$ The author also showed that the patients receiving the dose more slowly experienced their emetic episodes later in the postoperative period as opposed to patients receiving a bolus who developed nausea and vomiting immediately postoperatively. ${ }^{42}$ There is no difference in the incidence of PONV with the use of different kinds of opioids. ${ }^{26}$

\section{Surgery Related}

Sinclair, in his study along with Chung and Mezei had shown that patient undergoing breast surgery had about $41.5 \%$ incidence of PONV in early postoperative phase and $42.95 \%$ after 24 hours of operation.43The author found $16 \%$ suffered from PONV those undergoing shoulder orthopaedic surgery. ${ }^{43}$ There was $22 \%$ who felt PONV in Opthalmology department those undergoing strabismus surgery. ${ }^{43}$ The thyroid surgery, gynaecological surgery, orthopaedic knee and orthopaedic(other) surgery had also a significant number of PONV. ${ }^{43}$ In another study the authors found that PONV was highest in the women undergoing laparoscopic ovum retrieval procedures (54\%), followed by laparoscopy (35\%). ${ }^{44}$ In that study other surgeries like dental extractions, dilatation and curettage of the uterus, or knee arthroscopy had equal tendency of nausea and vomiting (16\%,12\%, and $22 \%$ respectively) ,they also reported high incidence of PONV after extracorporeal shock wave lithotripsy, head and neck surgery and stomach, duodenum and gall bladder operations. ${ }^{44}$ In paediatric patient strabismus surgery and tonsilloadenoidectomy surgery have highest incidence of PONV in comparison to the other surgeries. ${ }^{12,24}$ However Apfel CC, Kranke P, Eberhart LH did not find significant relation of surgical sight and PONV in their study. ${ }^{45}$

\section{In Paediatrics}

In paediatric patient, nausea can't be assessed so vomiting is the end point. POV(Post-operative vomiting) in children ranges from $33.2 \%$ to $80 \%$. $^{24}$ There is no difference in incidence of POV in male and female before puberty. ${ }^{13,26}$ Most of the risk factor are same for children as in adult but there is significant difference in some aspects. Strabismus surgery, age $\geq 3$ years, positive history of POV in the children or PONV in their relatives(mother, father or siblings), surgery $\geq$ to 30 minutes are identified as independent risk factor for POV in children. ${ }^{46}$ Each risk factor is given 1 point. They carry $9 \%, 10 \%, 30 \%, 55 \%$ or $70 \%$ risk of POV respectively for $0,1,2,3$, and 4 points ${ }^{46}$ as shown in table 2 .

Table 2: Risk factors of POV for children.
\begin{tabular}{|l|c|c|c|}
\hline Risk factors & Points & Score & $\begin{array}{c}\text { POV risk } \\
\%\end{array}$ \\
\hline None & 0 & 0 & 9 \\
\hline Surgery $\geq$ to 30 minutes & 1 & 1 & 10 \\
\hline Age $\geq 3$ years & 1 & 2 & 30 \\
\hline Strabismus surgery & 1 & 3 & 55 \\
\hline $\begin{array}{l}\text { History of POV } \\
\text { or PONV in relatives }\end{array}$ & 1 & 4 & 70 \\
\hline Total & $\mathbf{0 - 4}$ & & \\
\hline
\end{tabular}

Based on original article by GAN et al. ${ }^{5}$

\section{PREVENTION OF PONV}

Measures that can be taken to reduce the baseline risk factor

\section{Regional anaesthesia}

Use of regional anaesthesia instead of general anaesthesia can reduce the PONV by 11 times. ${ }^{12}$ However hypotension induced by spinal anaesthesia can also cause PONV. ${ }^{47}$ Ratra ck and friends in their study have suggested the use of $100 \%$ oxygen for the prevention of nausea and vomiting induced by the spinal anaesthesia suggesting that hypoxia induced by the spinal anaesthesia in the vomiting centre might play the role in nausea and vomiting after spinal anaesthesia and also maintenance of systolic blood pressure above $80 \mathrm{~mm}$ hg decreased the PONV significantly. ${ }^{48}$ Epidural anaesthesia has a lower incidence of nausea and vomiting postoperative than a general anaesthesia in a woman under going laparoscopic procedures. ${ }^{49}$

\section{Avoidance of volatile anaesthesia}

Use of propofol instead of volatile agents for induction and maintenance of anaesthesia can decrease the incidence of early occurrence of PONV(0-6hours post-operative) by 19 percent. ${ }^{50}$ Apfel cc and friends showed in their randomized controlled study that volatile anesthetics significantly increased the incidence of early PONV (0-2hrs) which had a dose response relationship. ${ }^{30}$ G.kumar and friends had shown in their systemic review and meta analysis, TIVA including propofol have a less PONV than the sevoflorane and desflorane anesthesia. ${ }^{51}$

\section{$\mathrm{N}_{2} \mathrm{O}$ abstinence}

Apfelcc and his colleagues in their study have shown that avoiding $\mathrm{N}_{2} \mathrm{O}$ by using nitrogen can decrease PONV by 12 $\%{ }^{50}$ However Tramer, $\mathrm{M}$ and his colleagues in their study showed that $\mathrm{N}_{2} \mathrm{O}$ have little impact on the PONV when the baseline risk factor or PONV is less and also intraoperative awareness was increased when $\mathrm{N}_{2} \mathrm{O}$ was omitted. ${ }^{52}$

\section{Reducing perioperative opioid use}

Decreasing the use of opioidsin traoperative and post operatively contributes to control PONV.-5 A multimodal pain regimen can effectively reduce the perioperative opioid use. ${ }^{5}$ Multimodal pain management and reduction of opioid 
use and the side effect of opioid use including nausea and vomiting is one the main target of ERAS. ${ }^{53}$ Acetaminophen, NSAIDS (non-steroidal anti-inflammatory drugs), Regional anaesthetic technique (neuraxial or peripheral block), gabapentanoids, lidocaine, tramadol,N-methy-Daspartateantagonists (eg-ketamine, dextromethorphan, magnesiumsulphate, methadone), alpha 2 agonists (dexmedetomidine and clonidine) are some analgesic methods which can be used to reduce the consumption of opioids. ${ }^{53}$ However opioids have been a main stream of pain management since a long time, total omission of opioid use is a difficult task though its use can be decreased via multimodal pain management methods.

\section{Management of pain and anxiety}

Pain can also induce nausea and vomiting thus controlling pain adequately with multimodal pain management and effectively reduce the incidence of PONV. ${ }^{53}$ Preoperative anxiety can increase the incidence of PONV. ${ }^{13-26}$ Thus Preoperative anxiety reduction with benzodiazepines can also help in reduction of PONV. ${ }^{54}$

\section{Others}

Some studies have shown that high dose neostigmine i.e> $2.5 \mathrm{mg}$ can induce PONV. ${ }^{54}$ However meata analysis done by Cheng C-R, Sessler DI, Apfel CC did not find the relations of neostigmine use and PONV. ${ }^{54}$ BIS guided anaesthesia has shown decrease in the occurrence of post-operative nausea and vomiting and fast recovery due to avoidance of unnecessary use of emetogenic anaesthetic agent in larger amount. $^{54}$

\section{Pharmacological intervention available for PONV}

Currently available pharmacological drugs for PONV acts on one of the different receptors that trigger vomiting.

\section{5-HT3 Receptor antagonist:}

5-HT3 receptor antagonist are the most commonly used and effective antiemetic available for PONV. ${ }^{55}$ They are superior than the traditional antiemietics used for PONV. ${ }^{56}$ 5-HT3 receptors are found in central CTZ and peripheral vagus nerve terminals, stimulation of either of the receptors triggers the vomiting centre. ${ }^{56}$ Ondasetron, dolasetron, granisetronare commonly used selective $5 \mathrm{HT}-3$ receptor antagonist. ${ }^{55}$ Palonesetron is a new member in this group which can effectively reduce the PONV in single IV dose of $0.075 \mathrm{mg} .{ }^{57} 5-\mathrm{HT} 3$ receptors bind and block peripheral and central emetogenic signals to the vomiting centre and prevent PONV. ${ }^{55}$ Most common side effect of $5 \mathrm{HT}-3$ receptor antagonists is headache followed by asthenia, constipation, diarrhoea, dizziness, insomnia, dyspepsia, decreased appetite, increased liver enzymes and abnormal vision. ${ }^{58}$ Studies have shown that $32 \mathrm{mg}$ of ondansetron and $2.4 \mathrm{mg} / \mathrm{kg}$ of dolasetron can significantly prolong the QTC interval. ${ }^{58}$ However the incidence of torsade's point and cardiac arrhythmias are very rare with the therapeutic doses. ${ }^{58,59}$ Palonestron hasn't shown tendency of prolonging QTC interval. ${ }^{57}$

\section{Cholinergic receptor antagonist:}

Atropine and scopolamine act centrally inhibiting muscarinic receptors in cerebral cortex and pons. ${ }^{60}$ Scopolamine has an antiemetic property in motion sickness and PONV. ${ }^{50}$ Transdermal formulation of scopolamine is associated with reduction of PONV both in early and late phase. ${ }^{61}$ The adverse effects of scopolamine includes inhibition of secretion of saliva causing dry mouth, also decreases sweat, decreases gastrointestinal secretion and motility.61lt also causes drowsiness, dilates pupils, increases heart rate and urine retention. ${ }^{61}$ The most common adverse effect of scopolamine is visual disturbance which can last for 24- 48 postoperative hours. ${ }^{63}$

\section{Dopamine receptor antagonist:}

The most common and dopamine antagonist used for the prevention of PONV ismetoclopramide..$^{64}$ It has been used for the prevention of PONV since long time. It actson central dopaminergic receptors ( D2 receptors), and central and peripheral 5-HT-3 receptors and on peripheral 5-HT-4 receptors. ${ }^{65}$ Since it blocks the central dopamine receptor extrapyramidal side effect can be its adverse effect however the antiemetic dose of the metoclopramide used most often is $10 \mathrm{mg}$ which does not show any extra pyramidal side effect, in addition there is no evidence of serious adverse reaction in chemotherapy where the dose of metoclopramide is very high. ${ }^{65,66}$ The most common adverse effect experienced are sedation and drowsiness and headache but they are also clinically not significant. ${ }^{66}$

Droperidol is a butyrophenone, a centrally acting dopamine D2 antagonist having an antiemetic action with more pronounce effect in nausea than in vomiting and have a short lived action. ${ }^{67}$ Apfel cc and his colleagues have shown that the droperidol have comparable clinical efficacy on both nausea and vomiting. ${ }^{68}$ The adverse reaction of droperidol includes extrapyramidal symptoms like restlessness and abnormal movements, sedation and drowsiness which are dose dependant. Sedation and drowsiness is not seen in the dose $0.25-0.625 \mathrm{mg}^{67}$ It might cause other adverse reaction like hypotension, anxiety, visual disturbance, night mares, oculogyric crisis, and urinary retention but they occur in very small number of patient and doesn't have serious issues. ${ }^{67}$ However the FDA had issued "Black box " warning regarding the use of Droperidol as it provokes the prolongation of QTc interval and was reported to provoke serious cardiac arrhythmias. ${ }^{69}$ However $1.25 \mathrm{mg}$ or dose below it does transient prolongation of QTc without any risk of torsade genic action. $^{70}$

Haloperidol is a butyrophenone, another potent antidopaminergic agent which is most commonly used as antipsychotic and to control severe agitation. ${ }^{71}$ It is being used in treatment of cancer patient as antiemetic successfully for a long time. ${ }^{72}$ Haloperidol is effective in prevention of PONV in the dose from $0.5 \mathrm{mg}$ to $1 \mathrm{mg} .^{73}$ The most common adverse reaction of haloperidol is extrapyramidal side effects, neuroleptic malignant syndrome, orthostatic hypotension, and electrocardiographic 
changes. ${ }^{74,75}$ QTc prolongation and torsade point can occur with haloperidol however it occurs more in psychiatric patient receiving35 $\mathrm{mg}$ (IV, oral or IM) in 24 hours. $^{74,75}$ It should be avoided in patient who have a risk factor for QTC interval prolongation such as the electrolyte disorder, congestive heart failure, cardiac hypertrophy, acute or chronic dysrhythmia, and patient taking tricyclic antidepressant and monoamine oxidase inhibitors. ${ }^{76}$

\section{Histamine receptor antagonist:}

Vestibular system and nucleus tractussolitarius at the vomiting centre have a $\mathrm{H} 1$ receptor which can be blocked efficiently by antihistamines such as diphenhydramine, dimenhydrinate, cyclizine and promethazine for prevention of PONV. ${ }^{77}$ However the adverse reactions like drowsiness, urinary retention, dry mouth and blurred vision has been reported. ${ }^{78}$

\section{Dexamethasone:}

Dexamethasone is a corticosteroid which has been successfully used for prevention of PONV. De Oliveira GS Jr and colleagues have shown the effectiveness of dexamethasone $4 \mathrm{mg}$ or $5 \mathrm{mg}$ similar to that of $8 \mathrm{mg}$ or $10 \mathrm{mg}$ in their study. ${ }^{79}$ The best prophylaxis of postoperative nausea and vomiting currently available is achieved by combining dexamethasone with a 5-HT3 receptor antagonist. ${ }^{79}$ However the exact mechanism of its antiemetic property is still not clear. Chiu-Ming $\mathrm{Ho}$ and colleagues have demonstrated the antiemetic action of dexamethasone in cat via activation of glucocorticoid receptors in bilateral NTS but not in area postrema, in the brain stem. ${ }^{80}$ Dexamethasone might prevent PONV via inhibiting prostaglandin synthesis, reducing serotonin activity and changing permeability of blood-brain barrier to plasma proteins. ${ }^{81,82}$ The antiinflammatory action of dexamethasone which significantly decreased the production of IL- 6 a potent pro-inflammatory cytokine produced by $\mathrm{T}$ cells and macrophage, may also have a role in prevention of PONV. ${ }^{83}$ The main adverse effect of dexamethasone is increase in blood sugar level and infection, however a single low dose of dexamethasone does not have a significant adverse effect. ${ }^{84}$

\section{NK1 antagonist (aprepitant):}

Neurokinin-1 receptors are found in the gastrointestinal vagal afferent and nucleustractussolaterius which can be activated by substance $P$ and cause nausea and vomiting. ${ }^{85}$ Neurokinin- 1 antagonist is a new class of drug that can be used in post-operative nausea and vomiting which effectively blocks the NK-1 receptors. ${ }^{86}$ Aprepitantis a first neurokinin-1 antagonist that was approved for the use in post-operative nausea and vomiting. Aprepitantappears to be superior in prevention of vomiting in comparison to the ondansetron and other drugs of 5HT-3 antagonists class. ${ }^{88}$ NK1 antagonist is free sedation and does not have any effect on QTc interval. ${ }^{88}$ However it can modestly induce CYP3A4 and CYP2C9 enzymes,more significantly on day 8 after the initiation of the treatment so the PT(prothrombin time ) and INR (International normalised ratio) should be closely monitored particularly at $7-10^{\text {th }}$ day of start of aprepitant for those who are on chronic therapy of warfarin which has a narrow therapeutic index. ${ }^{89}$

\section{Opioidantagonists:}

Opioid induces the nausea and vomitingby acting on CTZ in area postrema of the medulla by mediatingvomiting centre in the brainstem as shown by elimination of emetic effect of opioids on ablation of postrema. ${ }^{90} \mathrm{Gan} \mathrm{T} J$ and colleagues have illustrated that infusion of $0.25 \mathrm{mg} / \mathrm{kg} / \mathrm{hr}$ of the naloxone decreases the incidence of PONV as well as other side effects of morphine in PCA. ${ }^{91}$ Methylnaltrexone blocked the emetic action of opioids without altering the analgesic effect in animal studies. ${ }^{92}$ Opioids decreases the gastric motility and induces constipation which is also a factor for nausea and vomiting. ${ }^{93}$ Weese and colleagues demonstrated that use of alvimopan can reduce the postoperative ileus and PONV as well. ${ }^{93}$

\section{Ephedrine:}

Ephedrine is a sympathomimetic drug which increases the mean arterial blood pressure via acting through sympathetic nervous system. ${ }^{94} \mathrm{E}$. Hagemann and colleagues have demonstrated that ephedrine $0.5 \mathrm{mg} / \mathrm{kg}$ I.M. given at the end of abdominal hysterectomy has significantly reduced PONV for the first $3 \mathrm{~h}$ without presence of adverse drug reaction. ${ }^{95}$ D.M.Rotherberg and colleagues also concluded the efficacy of ephedrine $0.5 \mathrm{mg} / \mathrm{kg} \mathrm{IM}$ (intramuscular) without any sedative effect in comparison with the droperidol. ${ }^{94}$ The antiemetic action of ephedrine has been speculated because of its prevention of hypotension. ${ }^{94}$ Also, its action against the motion sickness is also thought to be the cause of its antiemetic property. ${ }^{26}$ However Hagemann and colleague were able to demonstrate that it has unique property of antiemetic besides prevention of hypotension induced by general or regional anaesthesia and motion sickness. ${ }^{95}$ Increase in heart rate and blood pressure are main concern of ephedrine however in low dose of $0.5 \mathrm{mg} \mathrm{IM}$, this adverse effect does not seem to occur. ${ }^{95}$

\section{Propofol:}

Propofol is a 2,6-diisopropylphenol; Diprivan, Astra Zeneca Pharmaceuticals, Wilmington, DE) which has a very good response as the intravenous anaesthetic that helps to reduce the PONV. ${ }^{96}$ Propofol acts on presynaptic and postsynaptic gamma-aminobutyric acid type A (GABA (A)) receptors which are found throughout the central nervous system and are associated with fast neuronal inhibition. ${ }^{96}$ Many studies have established its antiemetic effect.TIVA (Total intravenous anaesthesia) using propofol as a continuous infusion compared with inhalational agents have a lower incidence of PONV. ${ }^{51}$ Borgeat and colleagues in their study demonstrated that propofolin sub hypnotic doses i.e. $10 \mathrm{mg}$ possesses direct antiemetic effect in the context of minor elective surgery and also the adverse effect was rare in that dose..$^{97}$ Gan T.J and colleagues found that the plasma concentration required for the antiemetic action of the propofol is $343 \mathrm{ng} / \mathrm{ml}$ which corresponds to the bolus dose of $10 \mathrm{mg}$ followed by $10 \mathrm{mg} / \mathrm{kg} / \mathrm{min}$ infusion. ${ }^{98}$ 
Though the antiemetic mechanism of propofol is not clearly understood, there are various proposed mechanisms. Diflorio $T$ proposed that propofol acts via dopaminergic receptor. ${ }^{99}$ Propofol may have supressed various emetic centres like CTZ, vagal nuclei and other nausea and vomiting centres for its anti-emetic action. ${ }^{98}$ Also Collins and colleagues have demonstrated that propofolcan reduce the synaptic transmission in the olfactory cortex which decreases the release of excitatory amino acids like aspartate and glutamate that can be related with antiemetic action of propofol. ${ }^{100}$ Gelb AW and colleagues have found that continuous propofol infusion of $333-417 \mu \mathrm{g} / \mathrm{kg} / \mathrm{m}$ for 6 hours can decreases the level of serotonin in postrema. ${ }^{101}$ However the cost of the TIVA with propofol is expensive compared to the inhalational agents ${ }^{102}$, and continuous infusion of thepropofol postoperatively requires monitoring which is only possible in PACU (post anaesthetic care unit), intensive care unit or similar kinds of unit. ${ }^{96}$

\section{Non pharmacological methods:}

Acupuncture is effective in prevention of PONV. ${ }^{103}$ Acupoint PC6 is generally used for the prevention of PONV..$^{104}$ It can be used with various methods like manual manipulation, electroacupuncture, acupressure, transcutaneous electrical acustimulation (TEAS), or transcutaneous electrical nerve stimulation and laser stimulation. ${ }^{104}$ Chinese $P 6$ point is located at three finger breadth proximal to the proximal flexor palmar creases, between the tendons of the flexor carpi radialis and palmaris longus. ${ }^{103}$ Korean hand acupressure is a new kind of acupuncture that is different from the chinese acupuncture which includes K-K9 and K-D2 acupressure point that are located in palmar aspect of the middle phalanx of the fourth finger and dorsum of the lateral aspect of the distal phalanx of the index finger respectively. ${ }^{103}$ Schlagler A have demonstrated the efficacy of Korean hand acupressure in prevention of nausea and vomiting in both adult undergoing gynaecological laparoscopic surgery ${ }^{105}$ and children undergoing strabismus surgery. ${ }^{106}$

Table 3: Antiemetic doses and timing for prevention of postoperative nausea and vomiting.

\begin{tabular}{|l|l|l|}
\hline Drugs & Dose & Timing \\
\hline Dexamethasone & $4-5 \mathrm{mg}, \mathrm{IV}$ & At induction \\
\hline Dimenhydrinate & $1 \mathrm{mg} / \mathrm{kg}, \mathrm{IV}$ & \\
\hline Dolasetron & $12.5 \mathrm{mg}, \mathrm{IV}$ & $\begin{array}{l}\text { End of surgery; timing } \\
\text { may not affect efficacy }\end{array}$ \\
\hline Droperidol & $0.625-1.25 \mathrm{mg}, \mathrm{IV}$ & End of surgery \\
\hline Ephedrine & $0.5 \mathrm{mg} / \mathrm{kg}, \mathrm{IM}$ & End of surgery \\
\hline Granisetron & $0.35-1.5 \mathrm{mg}$, IV & End of surgery \\
\hline Haloperidol & $0.5-<2 \mathrm{mg}, \mathrm{IM} / \mathrm{IV}$ & \\
\hline Prochlorperazine & $5-10 \mathrm{mg}, \mathrm{IM} / \mathrm{IV}$ & End of surgery \\
\hline Promethazine & $6.25-25 \mathrm{mg}, \mathrm{IV}$ & At induction \\
\hline Ondasetron & $4 \mathrm{mg}, \mathrm{IV}$ & End of surgery \\
\hline Scopolamine & $\begin{array}{l}\text { Transdermal } \\
\text { patch }\end{array}$ & $\begin{array}{l}\text { Prior evening or } \\
4 \mathrm{~h} \text { before surgery }\end{array}$ \\
\hline Tropisetron & $2 \mathrm{mg}, \mathrm{IV}$ & End of surgery \\
\hline
\end{tabular}

Based on the original article by Gan et $\mathrm{al}^{5}$

Table 4: Antiemetic doses in children for postoperative
vomiting prophylaxis
\begin{tabular}{|l|l|}
\hline Drug & Dose \\
\hline Dexamethasone & $150 \mathrm{mcg} / \mathrm{kg}$ up to $5 \mathrm{mg}$ \\
\hline Dimenhydrinate & $0.5 \mathrm{mg} / \mathrm{kg}$ upto $25 \mathrm{mg}$ \\
\hline Dolasetron & $350 \mathrm{mcg} / \mathrm{kg}$ upto $12.5 \mathrm{mg}$ \\
\hline Droperidol $^{\mathrm{a}}$ & $10-15 \mathrm{mcg} / \mathrm{kg}$ upto $1.25 \mathrm{mg}$ \\
\hline Granisetron $^{\mathrm{b}}$ & $40 \mathrm{mcg} / \mathrm{kg}$ upto $0.6 \mathrm{mg}$ \\
\hline Ondasetron $^{\mathrm{b}}$ & $50-100 \mathrm{mcg} / \mathrm{kg}$ upto $4 \mathrm{mg}$ \\
\hline Tropisetron $^{\mathrm{m}}$ & $0.1 \mathrm{mg} / \mathrm{kg}$ up to $2 \mathrm{mg}$ \\
\hline
\end{tabular}

Based on the original article by Gan et $\mathrm{al}^{5}$

${ }_{a}$ See food and drug administration (FDA) "black box" warning.

Recommended doses 10 to $15 \mu \mathrm{g} / \mathrm{Kg}$.

${ }_{b} A p p r o v e d$ for POV in paediatric patients aged one month and older.

\section{PROPHYLAXIS FOR PONV}

Patient should be evaluated for the risk of PONV with available risk factor analysis method. The patient with low risk factor is recommended for PONV prophylaxis only if they are with wired jaws or increased intracranial pressure or if they are having fundo plication surgery. ${ }^{5}$ Two or more antiemetic therapy should be used for the patient with moderate or high risk factor and regional aesthesia should be used if possible after reducing baseline risk factor. Multimodal combination drug therapy with different mechanism of action is superior to the monotherapy. ${ }^{107}$ Prophylactic antiemetic if used according to the risk factor of the patient will help to minimize the unnecessary use of antiemetic and also help to reduce the side effect of the medications. See table 5 and 6.

Table 5: Pharmacological combination therapy of PONV for Adults and children

Adults

Droperidol+dexamethasone

$5 \mathrm{HT}-3$ receptor antagonist +dexamethasone

5HT-3 receptor antagonist + droperidol

$5 \mathrm{HT}-3$ receptor antagonists

+dexamethasone +droperidol

Based on Society for Ambulatory Anaesthesia Guidelines for the Management of Postoperative Nausea and Vomiting. ${ }^{3}$

\section{Children}

Ondasetron, $0.05 \mathrm{mg} / \mathrm{kg}$ +dexamethasone, $0.015 \mathrm{mg} / \mathrm{kg}$

Ondasetron, $0.1 \mathrm{mg} / \mathrm{kg}+$ droperidol, $0.015 \mathrm{mg} / \mathrm{kg}$

Tropesitron, $0.1 \mathrm{mg} / \mathrm{kg}+$ dexamethasone, $0.5 \mathrm{mg} / \mathrm{kg}$ 
Table 6: Prophylaxis treatment of PONV Based on the patient's level of Risk determined by Risk Factor Assessments.

\begin{tabular}{|l|c|c|c|c|}
\hline Level of risk & Low risk & $\begin{array}{c}\text { Moderate } \\
\text { risk }\end{array}$ & $\begin{array}{c}\text { Severe } \\
\text { risk }\end{array}$ & $\begin{array}{c}\text { Very } \\
\text { severe risk }\end{array}$ \\
\hline$\%$ chance of PONV & $10-20 \%$ & $40 \%$ & $60 \%$ & $80 \%$ \\
\hline $\begin{array}{l}\text { Number of prophylactic } \\
\text { intervention to consider }\end{array}$ & 0 & 1 & 2 & 3 or more \\
\hline
\end{tabular}

Based on ASPAN'S Evidence-Based Clinical Practice Guideline for the Prevention and/or management of PONV/PDNV ${ }^{108}$

\section{Strategy for rescue therapy for PONV in PACU}

When prophylaxis with the antiemetic fails to prevent PONV, the antiemetic from different class should be used which has not been used for prophylaxis. ${ }^{109}$ There is no benefit of repeating the same antiemetic or antiemetic from same class within the $6 \mathrm{hrs}$ of use of the antiemetic as a prophylaxis for established PONV. ${ }^{110}$ Low doses of $5 \mathrm{HT}-3$ antagonists i.e. ondansetron, $1 \mathrm{mg}$, dolasetron, $12.5 \mathrm{mg}$, granisetron, $0.1 \mathrm{mg}$ and Tropisetron, $0.5 \mathrm{mg}$ can be used if no prophylaxis has been given for the treatment of established PONV. ${ }^{111}$ Promethazine, 6.25 to $25 \mathrm{mg}$ IV is better than metoclopramide, $10 \mathrm{mg}$ and droperidol, $0.625 \mathrm{mg}$ in treatments for established PONV. ${ }^{109}$ Propofol, $20 \mathrm{mg}$, can also be used for rescue therapy in patients in the PACU ${ }^{109}$ which is as effective as ondansetron. ${ }^{112}$ However, the antiemetic effect is of short time duration with low dose propofol. ${ }^{113}$ Isopropyl alcohol is not recommended for the treatment of established PONV. Readministraion of 5 HT-3 antagonist might be useful if administered after $6 \mathrm{hrs}$ of its administration as prophylaxis however long acting antiemetics like dexamethasone, TDS (transdermal scolopolamine), apropitant, palonosetron are not recommended to readminister for control of established PONV. ${ }^{5}$

\section{DISCUSSIONS}

As stated by Kapur PA in 1991 PONV is a big little problem ${ }^{1}$ and is still a problem. Patients undergoing surgery under general anaesthesia complains nausea and vomiting more troublesome than the pain and are willing to pay more amounts for its prevention and treatment. ${ }^{8}$ Female Gender, Non-smoking status, perioperative opioid use, h/o motion sickness and PONV has been regarded as the definite risk factor although length of surgery, types of surgery (Strabismus surgery, Intra abdominal, ENT, thyroid, breast, gynaecological, neurological surgery), inhalational anaesthesia, age, N20, are also regarded as a risk factor contributing to PONV., ${ }^{212-14}$ Many guidelines are available for its prevention and reduction. ${ }^{3,5}$ Reduction of baseline factor by using regional anaesthesia, using propofol instead of inhalation for induction and maintenance, reduction of opioids use, use of multimodal pain management can reduce incidence of PONV. ${ }^{5}$ PONV is still occurring even after using multiple drugs for its prevention. Multimodal approach can be used for its prevention. Use of multiple drugs with different mechanism of action has shown better efficiency than the single drug for the prevention of PONV. Drugs should be used according to the risk factor to reduce its unnecessary use and prevent from its side effects. However both pharmacological and non-pharmacological method and risk reduction approach has failed to prevent it, as one third of the surgical patient still experiences PONV. Lots of studies has been done for its prophylaxis and prevention but very few studies has been done for the rescue drugs and its efficiency in PACU that can be used when PONV occurs even after using multimodal approach for the prevention of PONV. Researches needed to be done for the treatment of PONV that occurs in PACU even in the presence of prophylactic antiemetic, that might help the patient to get rid from the bad experience they have in PACU due to nausea and vomiting and help to discharge them early from PACU and ultimately from hospital. Rescue drugs should be used from different classes of drugs that has not been used for prophylaxis. Prevention and treatment of PONV effectively can help in cost reduction for the patient due to early discharge and also provide patient satisfaction after operation.

\section{CONCLUSION}

Without prophylactic intervention, PONV will develop in about one third of patients (range, $10 \%$ to $80 \%$ ) who undergo general anaesthesia without any prophylactic intervention. The effect of PONV includes late discharge from the PACU, prolonged hospital admission, increased chances of pulmonary aspiration, and significant postoperative discomfort. The ability to identify high-risk patients for prophylactic intervention can significantly improve the quality of patient care and satisfaction in the PACU.

Thus, depending upon the risk factor and chances of PONV, prophylaxis should be given with monotherapy or combination therapy. All prophylaxis in children at moderate or high risk for postoperative vomiting should include combination therapy using a 5-HT3 antagonist and a second drug from other class. Because the effects of interventions from different drug classes are additive, combining interventions has an additive effect in risk reduction.

When rescue therapy is required, the antiemetic should be chosen from a different therapeutic class than the drugs used for prophylaxis.

Though we tried to include all the available regimens pharmacological and non-pharmacological methods of prevention and treatment of PONV, we are not in position to suggest the ideal drug for the treatment of PONV. 


\section{ACKNOWLEDGEMENT}

I would like to thank department of anaesthesia of Harbin medical university. I would specially like to mention Dr. Rupesh Yadav, Head of department Anaesthesia of National Trauma centre for his valuable suggestion for this review article.

\section{REFERENCES}

1. Kapur PA. The big "little problem". Anesth Analg. 1991;73(3):243245.

2. Apfel CC, Lä ä rä E, Koivuranta M, Greim C-A, Roewer N. A Simplified Risk Score for Predicting Postoperative Nausea and Vomiting Conclusions from Cross-validations between Two Centers. Anesthesiology. 1999;91(3):693-700. doi:10.1097/00000542199909000-00022

3. Gan TJ, Meyer TA, Apfel CC, et al. Society for ambulatory anesthesia guidelines for the management of postoperative nausea and vomiting. Anesth Analg. 2007;105(6):1615-1628. doi:10.1213/01. ane.0000295230.55439.f4

4. Gan TJ, Meyer T, Apfel CC, et al. Consensus Guidelines for Managing Postoperative Nausea and Vomiting. Anesth Analg. 2003:62-71. doi:10.1213/01.ANE.0000068580.00245.95

5. Gan TJ, Diemunsch P, Habib AS, et al. Consensus guidelines for the management of postoperative nausea and vomiting. Anesth Analg. 2014;118(1):85-113. doi:10.1213/ANE.0000000000000002

6. Gold BS, Kitz DS, Lecky JH, Neuhaus JM. Unanticipated admission to the hospital following ambulatory surgery. JAMA. 1989;262(21): 3008-3010.

7. Fortier J, Chung F, Su J. Unanticipated admission after ambulatory surgery--a prospective study. Can J Anaesth. 1998;45:612-619. doi:10.1007/BF03012088

8. Gan T, Sloan F, Dear G de L, El-Moalem HE, Lubarsky DA. How much are patients willing to pay to avoid postoperative nausea and vomiting? Anesth Analg. 2001;92(2):393-400.

9. Balzano G, Zerbi A, Braga M, Rocchetti S, Beneduce AA, Di Carlo V. Fast-track recovery programme after pancreatico- duodenectomy reduces delayed gastric emptying. Br J Surg. 2008;95(11):13871393. doi:10.1002/bjs.6324

10. PALAZZO M, EVANS R. Logistic Regression Analysis of Fixed Patient Factors for Postoperative Sickness: a Model for Risk Assessment. Br J Anaesth. 1993;70(2):135-140. doi:10.1093/bja/70.2.135

11. Koivuranta M, Laara E, Snare L, Alahuhta S. A survey of postoperative nausea and vomiting. Anaesthesia. 1997;52(5):443-449. doi:10.1111/j.1365-2044.1997.117-az0113.x

12. Sinclair DR, Chung F, Mezei G. Can postoperative nausea and vomiting be predicted? Anesthesiology. 1999;91(1):109-118. doi:10.1097/00000542-199907000-00018

13. Lerman J. Surgical and patient factors involved in postoperative nausea and vomiting. Br J Anaesth. 1992;69(7 Suppl 1):24S-32S. doi:10.1093/bja/69.supplement

14. Apfel CC, Roewer N. Risk Assessment of Postoperative Nausea and Vomiting. Int Anesthesiol Clin. 2003;41(4):13-32. doi:10.1097/ 00004311-200341040-00004

15. Apfel CC, Greim CA, Haubitz I, et al. A risk score to predict the probability of postoperative vomiting in adults. Acta Anaesthesiol Scand. 1998;42(5):495-501. doi:10.1111/j.1399-6576.1998. tb05157.x

16. BELLVILLE JW. Postanesthetic nausea and vomiting. Anesthesiology. 1961;22:773-780.

17. Bellville J. Weldon MD, Bross Irwin D. J. PD, Howland William S. MD. POSTOPERATIVE NAUSEA AND VOMITING IVFACTORS RELATED TO POSTOPERATIVE NAUSEA AND VOMITING. Anesthesiology. 1960;21(2):186-193. http://dx.doi.org/.

\section{CONFLICT OF INTEREST}

I have no conflict of interest to declare.
18. Rowley MP, Brown TC. Postoperative vomiting in children. Anaesth Intensive Care. 1982;10(4):309-313.

19. Chatterjee S, Rudra A, Sengupta S. Current Concepts in the Management of Postoperative Nausea and Vomiting. Anesthesiol Res Pract. 2011;2011:748031. doi:10.1155/2011/748031

20. Conti $D$, Ballo $P$, Boccalini $R$, et al. The effect of patient sex on the incidence of early adverse effects in a population of elderly patients. Anaesth Intensive Care. 2014;42(4):455-459.

21. W. C, P. SB. The effect of smoking on postoperative nausea and vomiting. Anaesthesia. 2001;55(6):540-544. doi:10.1046/j.1365-2044. 2000. 01474.x

22. Conney AH, Pantuck EJ, Hsiao KC, Kuntzman R, Alvares AP, Kappas A. Regulation of drug metabolism in man by environmental chemicals and diet. Fed Proc. 1977;36(5):1647-1652. http://europepmc.org/ abstract/MED/844609.

23. Wrighton SA, Stevens JC. The Human Hepatic Cytochromes P450 Involved in Drug Metabolism. Crit Rev Toxicol. 1992;22(1):1-21. doi:10.3109/10408449209145319

24. Rose JB, Watcha MF. Postoperative nausea and vomiting in paediatric patients. Br J Anaesth. 1999;83(1):104-117. doi:10.1093/bja/83.1.104

25. Apfel CC, Philip BK, Cakmakkaya OS, et al. Who is at risk for post discharge nausea and vomiting after ambulatory surgery? Anesthesiology. 2012;117(3):475-486. doi:10.1097/ALN.0b013e318267ef31

26. Watcha MF, White PF. Postoperative nausea and vomiting. Its etiology, treatment, and prevention. Anesthesiology. 1992;77(1):162-184.

27. Kranke P, C Apefel C, Papenfuss T, et al. An Increased Body Mass Index Is No Risk Factor for Postoperative Nausea and Vomiting. A Systematic Review and Results of Original Data. Vol 45.; 2001. doi:10.1034/ j.1399-6576.2001.450205.x

28. Ong BY, Palahniuk RJ, Cumming M. Gastric volume and $\mathrm{pH}$ in outpatients. Can Anaesth Soc J. 1978;25(1):36. doi:10.1007/BF03006781

29. Jenkins LC, Lahay D. Central mechanisms of vomiting related to catecholamine response: anaesthetic implication. Can Anaesth Soc J. 1971;18(4):434-441.

30. Apfel CC, Kranke P, Katz MH, et al. Volatile anaesthetics may be the main cause of early but not delayed postoperative vomiting: a randomized controlled trial of factorial design. $\mathrm{Br} J$ Anaesth. 2002;88(5):659-668.

31. Forrest JB, Cahalan MK, Rehder K, et al. Multicenter study of general anesthesia. II. Results. Anesthesiology. 1990;72(2):262-268.

32. Macario A, Dexter F, Lubarsky D. Meta-analysis of trials comparing postoperative recovery after anesthesia with sevoflurane or desflurane. Am J Health Syst Pharm. 2005;62(1):63-68.

33. Leslie K, Myles PS, Chan MT V, et al. Risk factors for severe postoperative nausea and vomiting in a randomized trial of nitrous oxide-based vs nitrous oxide-free anaesthesia. Br J Anaesth. 2008;101(4):498-505. doi:10.1093/bja/aen230

34. Myles PS, Leslie K, Chan MT V, et al. Avoidance of nitrous oxide for patients undergoing major surgery: a randomized controlled trial. Anesthesiology. 2007;107(2):221-231. doi:10.1097/01.anes. 0000270723.30772.da

35. Fernandez-Guisasola J, Gomez-Arnau JI, Cabrera Y, del Valle SG. Association between nitrous oxide and the incidence of postoperative nausea and vomiting in adults: a systematic review and meta-analysis. Anaesthesia. 2010;65(4):379-387. doi:10.1111/j.1365-2044.2010. 06249.x 
36. Perreault L, Normandin N, Plamondon L, et al. Middle ear pressure variations during nitrous oxide and oxygen anaesthesia. Can Anaesth Soc J. 1982;29(5):428-434. doi:10.1007/BF03009404

37. EGER EI 2nd, SAIDMAN LJ. HAZARDS OF NITROUS OXIDE ANESTHESIA IN BOWEL OBSTRUCTION AND PNEUMOTHORAX. Anesthesiology. 1965;26:61-66

38. Hovorka J, Korttila K, Erkola O. Nitrous oxide does not increase nausea and vomiting following gynaecological laparoscopy. Can J Anaesth. 1989;36(2):145-148. doi:10.1007/BF03011437

39. Taylor E, Feinstein R, White PF, Soper N. Anesthesia for laparoscopic cholecystectomy. Is nitrous oxide contraindicated? Anesthesiology. 1992;76(4):541-543.

40. Ichinohe T, Kaneko Y. Nitrous oxide does not aggravate postoperative emesis after orthognathic surgery in female and nonsmoking patients. J Oral Maxillofac Surg. 2007;65(5):936-939. doi:10.1016/ j.joms.2006.06.283

41. Roberts GW, Bekker TB, Carlsen HH, Moffatt CH, Slattery PJ, McClure AF. Postoperative nausea and vomiting are strongly influenced by postoperative opioid use in a dose-related manner. Anesth Analg. 2005;101(5):1343-1348. doi:10.1213/01.ANE.0000180204.64588.EC

42. Woodhouse A, Mather LE. The effect of duration of dose delivery with patient-controlled analgesia on the incidence of nausea and vomiting after hysterectomy. $\mathrm{Br} J$ Clin Pharmacol. 1998;45(1):57-62. doi:10.1046/j.1365-2125.1998.00635.x

43. Sinclair DR, Chung F, Mezei G. Can postoperative nausea and vomiting be predicted? Anesthesiology. 1999;91(1):109-118

44. Patasky AO, Kitz DS, Andrews RW LJ. Nausea and vomiting following ambulatory surgery:Are all procedures created equal ? Anesth Analg. 1988;67(suppl)s((suppl)s):163.

45. Apfel CC, Kranke P, Eberhart LHJ. Comparison of surgical site and patient's history with a simplified risk score for the prediction of postoperative nausea and vomiting. Anaesthesia. 2004;59(11):10781082. doi:10.1111/j.1365-2044.2004.03875.x

46. Eberhart LHJ, Geldner G, Kranke P, et al. The development and validation of a risk score to predict the probability of postoperative vomiting in pediatric patients. Anesth Analg. 2004;99(6):1630-1637, table of contents. doi:10.1213/01.ANE.0000135639.57715.6C

47. Crocker JS VL. Concerning nausea and vomiting during spinal anesthesia. Anesthesiology. 1959;20:587-592.

48. Ratra CK, Badola RP, Bhargava KP. Brit. J. Anaesth. (1972), 44,1208 A STUDY OF FACTORS CONCERNED IN EMESIS DURING SPINAL ANAESTHESIA. 1972:1208-1211.

49. Day FOR, Surgery C. Regional anaesthesia for outpatient surgery- A summary of 12 years' experience. :548-552.

50. Apfel CC, Korttila K, Abdalla M, et al. A factorial trial of six interventions for the prevention of postoperative nausea and vomiting. N Engl J Med. 2004;350(24):2441-2451. doi:10.1056/ NEJMoa032196

51. Kumar G, Stendall C, Mistry R, Gurusamy K, Walker D. A comparison of total intravenous anaesthesia using propofol with sevoflurane or desflurane in ambulatory surgery: Systematic review and metaanalysis. Anaesthesia. 2014;69(10):1138-1150. doi:10.1111/anae.12713

52. Tramer M, Moore A, McQuay H. Omitting nitrous oxide in general anaesthesia: meta-analysis of intraoperative awareness and postoperative emesis in randomized controlled trials. Br J Anaesth. 1996;76(2):186-193.

53. Wick EC, Grant MC, Wu CL. Postoperative Multimodal Analgesia Pain Management With Nonopioid Analgesics and Techniques: A Review. JAMA Surg. 2017;152(7):691-697. doi:10.1001/jamasurg.2017.0898

54. Rodola F. Midazolam as an anti-emetic. Eur Rev Med Pharmacol Sci. 2006;10(3):121-126.

55. L G. 5-HT3 receptors: pharmacologic and therapeutic aspects. J ClinPharmacol. 1995;1995(35):845-855.

56. Loewen PS, Marra CA, Zed PJ. 5-HT3 receptor antagonists vs traditional agents for the prophylaxis of postoperative nausea and vomiting. Can J Anaesth. 2000;47(10):1008-1018. doi:10.1007/ BF03024875
57. Kovac AL, Eberhart L, Kotarski J, Clerici G, Apfel C. A randomized, double-blind study to evaluate the efficacy and safety of three different doses of palonosetron versus placebo in preventing postoperative nausea and vomiting over a 72-hour period. Anesth Analg. 2008;107(2):439-444. doi:10.1213/ane.0b013e31817abcd3

58. Goodin S, Cunningham R. 5-HT(3)-receptor antagonists for the treatment of nausea and vomiting: a reappraisal of their side-effect profile. Oncologist. 2002;7(5):424-436.

59. Benedict CR AR, Martin L et al. Single-blind study of the effects of intravenous dolasetron mesylate versus ondansetron on electrocar diographic parameters in normal volunteers. J Cardiovasc. 1996;28:53-59.

60. McCarthy B PS. Differentiation of muscarinic cholinergic receptor subtypes in human cortex and pons. 1988;59:63.

61. Kranke P, Morin AM, Roewer N. The Efficacy and Safety of Transdermal Scopolamine for the Prevention of Postoperative Nausea and Vomiting: A Quantitative Systematic Review. 2002;(2). doi:10.1213/01.ANE.0000021318.30928.AA

62. Spinks AB, Wasiak J, Villanueva E V, Bernath V. Scopolamine (hyoscine) for preventing and treating motion sickness. Cochrane database Syst Rev. 2007;(3):CD002851. doi:10.1002/14651858. CD002851. pub3

63. Apfel CC, Zhang K, George E, et al. Transdermal scopolamine for the prevention of postoperative nausea and vomiting: a systematic review and meta-analysis. Clin Ther. 2010;32(12):1987-2002. doi:10.1016/j.clinthera.2010.11.014

64. Jr GSDO, Chang R, Yaghmour E, Mccarthy RJ. Systemic metoclopramide to prevent postoperative nausea and vomiting : a meta-analysis without Fujii ' s studies. 2012;109(September):688697. doi:10.1093/bja/aes325

65. Henzi I, Walder B TM. Metoclopramide in the prevention of postoperative nausea and vomiting: a quantitative systematic review of randomized, placebo-controlled studies. Br J Anaesth. 1999;83:761-771.

66. Gralla RJ, Itri LM, Pisko SE, et al. Antiemetic efficacy of high-dose metoclopramide: randomized trials with placebo and prochlorperazine in patients with chemotherapy-induced nausea and vomiting. N Engl J Med. 1981;305(16):905-909. doi:10.1056/ NEJM198110153051601

67. Henzi I, Sonderegger J, Tramer MR. Efficacy, dose-response, and adverse effects of droperidol for prevention of postoperative nausea and vomiting. Can J Anaesth. 2000;47(6):537-551. doi:10.1007/BF03018945

68. Apfel CC, Cakmakkaya OS, Frings G, Kranke P, Malhotra A, Stader A. Droperidol has comparable clinical efficacy against both nausea and vomiting. 2009:1-5. doi:10.1093/bja/aep177

69. Habib AS, Gan TJ. Food and Drug Administration Black Box Warning on the. 2003;2001:2001-2003.

70. Tracz K, Owczuk R. Small doses of droperidol do not present relevant torsadogenic actions: a controlled study. 2014. doi:10.1111/bcp.12527

71. Aouad MT, Taha SK, Azar MS, Nasr VG, Hakki MA. Haloperidol vs. ondansetron for the prevention of postoperative nausea and vomiting following. 2007:171-178. doi:10.1017/S0265021506001323

72. Critchley P, Plach N, Grantham M, et al. Efficacy of haloperidol in the treatment of nausea and vomiting in the palliative patient: a systematic review. J Pain Symptom Manage. 2001;22(2):631-634.

73. Tornetta FJ. Double-blind evaluation of haloperidol for antiemetic activity. Anesth Analg. 1972;51(6):964-967.

74. Norred CL. Antiemetic prophylaxis: pharmacology and therapeutics. AANAJ. 2003;71(2):133-140.

75. Smith JC, Wright EL. Haloperidol: An alternative butyrophenone for nausea and vomiting prophylaxis in anesthesia. AANA J. 2005;73(4):273-275.

76. Tan HL, Hou CJ, Lauer MR, Sung RJ. Electrophysiologic mechanisms of the long QT interval syndromes and torsade de pointes. Ann Intern Med. 1995;122(9):701-714. 
77. Scuderi PE. Pharmacology of antiemetics. Int Anesthesiol Clin. 2003;41(4):41-66.

78. Kranke P, Morin AM, Roewer N, Eberhart LH. Dimenhydrinate for prophylaxis of postoperative nausea and vomiting: a meta-analysis of randomized controlled trials. Acta Anaesthesiol Scand. 2002;46(3):238-244.

79. De Oliveira GSJ, Castro-Alves LS, Ahmad S, Kendall MC, McCarthy RJ. Dexamethasone to prevent postoperative nausea and vomiting: an updated meta-analysis of randomized controlled trials. Anesth Analg. 2013;116(1):58-74. doi:10.1213/ANE.0b013e31826f0a0a

80. Ho CM, Ho ST, Wang JJ, Tsai SK, Chai CY. Dexamethasone has a central antiemetic mechanism in decerebrated cats. Anesth Analg. 2004;99(3):734-739. doi:10.1213/01.ANE.0000130003.68288.C7

81. Henzi I, Walder B, Tramer MR. Dexamethasone for the prevention of postoperative nausea and vomiting: a quantitative systematic review. Anesth Analg. 2000;90(1):186-194.

82. Ho C, Wu H, Ho S, Wang J. Acta Anaesthesiologica Taiwanica Dexamethasone prevents postoperative nausea and vomiting : Bene fi t versus risk. Acta Anaesthesiol Taiwanica. 2011;49(3):100104. doi:10.1016/j.aat.2011.06.002

83. Zargar-Shoshtari K, Sammour T, Kahokehr A, Connolly AB, Hill AG. Randomized clinical trial of the effect of glucocorticoids on peritoneal inflammation and postoperative recovery after colectomy. Br J Surg. 2009;96(11):1253-1261. doi:10.1002/bjs.6744

84. Holte K, Kehlet H. Perioperative single-dose glucocorticoid administration: Pathophysiologic effects and clinical implications. J Am Coll Surg. 2002;195(5):694-712. doi:10.1016/\$1072-7515(02) 01491-6

85. Leslie RA. Neuroactive substances in the dorsal vagal complex of the medulla oblongata: nucleus of the tractus solitarius, area postrema, and dorsal motor nucleus of the vagus. Neurochem Int. 1985;7(2):191-211.

86. Liu M, Zhang H, Du B-X, et al. Neurokinin-1 Receptor Antagonists in Preventing Postoperative Nausea and Vomiting: A Systematic Review and Meta-Analysis. Medicine (Baltimore). 2015;94(19). https://journals.Iww.com/md-journal/Fulltext/ 2015/05030/ Neurokinin_1_Receptor_Antagonists_in_Preventing.4.aspx.

87. Liu M, Zhang H, Du B-X, et al. Neurokinin-1 Receptor Antagonists in Preventing Postoperative Nausea and Vomiting. Medicine (Baltimore). 2015;94(19):e762. doi:10.1097/MD.0000000000000762

88. Apfel CC, Malhotra A, Leslie JB. The role of neurokinin-1 receptor antagonists for the management of postoperative nausea and vomiting. Curr Opin Anaesthesiol. 2008;21(4):427-432. doi:10.1097/ACO.0b013e328301831c

89. Shadle CR, Lee $Y$, Majumdar AK, et al. Evaluation of Potential Inductive Effects of Aprepitant on Cytochrome P450 3A4 and 2C9 Activity. J Clin Pharmacol. 2004;44(3):215-223. doi:10.1177/ 0091270003262950

90. WANG SC, GLAVIANO V V. Locus of emetic action of morphine and hydergine in dogs. J Pharmacol Exp Ther. 1954;111(3):329-334.

91. Downloaded From: http://anesthesiology.pubs.asahq.org/pd faccess.ashx?url=/data/journals/jasa/931328/on 02/18/2018. 2018.

92. Yuan CS. Methylnaltrexone mechanisms of action and effects on opioid bowel dysfunction and other opioid adverse effects. Ann Pharmacother. 2007;41:984-993. doi:10.1345/aph.1K009

93. Dorn S, Lembo A, Cremonini F. Opioid-Induced Bowel Dysfunction: Epidemiology, Pathophysiology, Diagnosis, and Initial Therapeutic Approach. Am J Gastroenterol Suppl. 2014;2(1):31-37. doi:10. 1038/ajgsup.2014.7

94. Rothenberg DM, Parnass SM, Litwack K, McCarthy RJ, Newman LM. Efficacy of ephedrine in the prevention of postoperative nausea and vomiting. Anesth Analg. 1991;72(1):58-61.

95. Hagemann E, Halvorsen A, Holgersen, Tveit T, Ræder JC. Intramuscular ephedrine reduces emesis during the first three hours after abdominal hysterectomy. Acta Anaesthesiol Scand. 2000;44(1):107-111. doi:10.1034/j.1399-6576.2000.440119.x
96. DeBalli P. The Use of Propofol as an Antiemetic. Int Anesthesiol Clin. 2003;41(4):67-77. doi:10.1097/00004311-200341040-00007

97. Borgeat A, Wilder-Smith OH, Saiah M, Rifat K. Subhypnotic doses of propofol possess direct antiemetic properties. Anesth Analg. 1992;74(4):539-541. doi:10.1213/00000539-199204000-00013

98. Gan FRCA, FFARCS(I), T. J. MB, Glass FFA(SA), P. S. A. MB, Howell S. T. MD, Canada A. T. P, Grant A. P. BS, Ginsberg B. MD. Determination of Plasma Concentrations of Propofol Associated with 50\% Reduction in Postoperative Nausea. Anesthesiology. 1997;87(4): 779-784. http://dx.doi.org/.

99. Diflorio T. Is propofol a dopamine antagonist? Anesth Analg. 1993;77(1):200-201.

100. G.G.S. C. Effects of the anaesthetic 2,6-diisopropylphenol on synaptic transmission in the rat olfactory cortex slice. Br J Pharmacol. 2018;95(3):939-949. doi:10.1111/j.1476-5381.1988. tb11724.x

101. Cechetto DF, Diab T, Gibson CJ, Gelb AW. The Effects of Propofol in the Area Postrema of Rats. Anesth Analg. 2001;92(4). https:// journals.Iww.com/anesthesia-analgesia/ Fulltext/2001/ 04000/ The_Effects_of_Propofol_in_the_Area_Postrema_of.27.aspx.

102. Visser Klazina MD, Hassink Elly A. PD, Bonsel Ph.D. ,Gouke J. MD, Moen Jeroen RN, Kalkman Ph.D., Cor J. MD. Randomized Controlled Trial of Total Intravenous Anesthesia with Propofol versus Inhalation Anesthesia with Isoflurane-Nitrous Oxide Postoperative Nausea and Vomiting and Economic Analysis. Anesthesiology. 2001;95(3):616-626. http://dx.doi.org/.

103. Rowbotham DJ. Recent advances in the non-pharmacological management of postoperative nausea and vomiting. $\mathrm{Br} J$ Anaesth. 2005;95(1):77-81. doi:10.1093/bja/aei125

104. Ouyang $\mathrm{H}$, Chen JDZ. Therapeutic roles of acupuncture in functional gastrointestinal disorders. Aliment Pharmacol Ther. 2004;20(8): 831-841. doi:10.1111/j.1365-2036.2004.02196.x

105. Boehler M, Mitterschiffthaler G, Schlager A. Korean hand acupressure reduces postoperative nausea and vomiting after gynecological laparoscopic surgery. Anesth Analg. 2002;94(4):872875 , table of contents. doi:10.1097/00000539-200204000-00018

106. Schlager $a$, Boehler M, Pühringer F. Korean hand acupressure reduces postoperative vomiting in children after strabismus surgery. Br J Anaesth. 2000;85(2):267-270. http://www.ncbi. nlm.nih. gov/pubmed/10992837.

107. Habib AS, Gan TJ. Combination therapy for postoperative nausea and vomiting-a more effective prophylaxis? Ambul Surg. 2001;9(2):59-71.

108. Practice AE. ASPAN'S Evidence-Based Clinical Practice Guideline for the Prevention and/or Management of PONV/PDNV. J Perianesthesia Nurs. 2006;21(4):230-250. doi:10.1016/j.jopan. 2006.06.003

109. Habib A, J Gan T. The Effectiveness of Rescue Antiemetics after Failure of Prophylaxis with Ondansetron or Droperidol: A Preliminary Report. Vol 17.;2005. doi:10.1016/j.jclinane. 2004.04.004

110. Kovac AL, O'Connor TA, Pearman MH, et al. Efficacy of repeat intravenous dosing of ondansetron in controlling postoperative nausea and vomiting: A randomized, double-blind, placebocontrolled multicenter trial. J Clin Anesth. 1999;11(6):453-459. doi:10.1016/S0952-8180(99)00067-7

111. Kazemi-kjellberg F, Henzi I, Tramèr MR. Treatment of established postoperative nausea and vomiting : a quantitative systematic review. 2001.

112. Unlugenc $H$, Guler T, Gunes $Y$, Isik G. Comparative study of the antiemetic efficacy of ondansetron, propofol and midazolam in the early postoperative period. Eur J Anaesthesiol. 2004;21(1):60-65.

113. Gan TJ, Glass PS, Howell ST, Canada AT, Grant AP GB. Determination of plasma concentration of propofol associated with $50 \%$ reduction in postoperative nausea. 